không có dịch COVID-19 xâm nhâp vào trong BV và công tác chuyên môn của $B V$ vẫn được đảm bảo thực hiện trong trạng thái bình thường mới.

Xét nghiệm nhanh kháng nguyên SARS-CoV-2 nên được triển khai phổ biến rộng rãi trong công đồng tới các thành viên "Tổ COVID-19", tới cán bộ viên chức các cơ quan doanh nghiệp, tới những người công nhân nhà máy xí nghiệp, khu công nghiệp ... để họ tự làm xét nghiệm sàng lọc giúp nâng cao năng lực xét nghiệm lên gấp nhiều lần, góp phần phát hiện rất sớm những trường hợp dương tính để cách ly.

\section{TÀI LIẸU THAM KHẢO}

1. Báo VNEXPRESS. Bộ trưởng Y tễ: 'Đợt dịch sau thường tàn khốc hớn lần trước'. Địa chì https://vnexpress.net/bo-truong-y-te-dot-dich-sauthuong-tan-khoc-hon-lan-truoc-4267918.html (truy câp ngày 28 tháng 5 năm 2021).

2. Bộ Y tế. Số 2020/QĐ-BYT. Quyết định ban hằnh Hướng dẫn sử dụng sinh phẩm xét nghiệm nhanh kháng nguyên vi rút SARS-CoV-2. 2021.
3. Bộ Y tế. Số 3740/BYT-TB-CT. Danh sách các sinh phẩm/trang thiết bi y tế chẩn đoán in vitro xét nghiệm vi rút SSARS-CoV-2 đã được cấp số đăng kỳ, cấp giấy phép nhập khẩu. 2021 .

4. WHO. WHO Emergency Use Listing for In vitro diagnostics (IVDs) Detecting SARS-CoV-2. Đia chỉ https://extranet.who.int/pqweb/sites/default/files/ documents/210126_eul_sars_cov2_product_list.pd $\mathrm{f}$ (truy cấp ngày 27 tháng 5 năm 2021). 2021.

5. Bệnh viên Phổi Trung ương. Ban Chỉ đạo phòng chống COVID-19. Mô hình bệnh viện an toàn ứng phó COVID-19. 2020.

6. Báo Sức khỏe và Đời sống. 2 ca nghi mắc COVID-19 tai BV Hữu Nghi. Đia chỉ https:// suckhoedoisong.vn/phat-hien-2-nguoi-nghi-nhiemcovid-19-ngay-tu-cong-bv-huu-nghi-n192302.html (truy câp ngày 29 tháng 5 năm 2021).

7. Bộ Y tề. Số 4352/BYT-MT. Công văn gửi UBND tỉnh/thành phố trức thuộc Tư và các Bôn ngành hướng dân cách ly, xét nghiệm trong các k̉hu công nghiệp, nhà máy, xí nghiệp. 2021.

8. Lambert-Niclot, S., et al., Evaluation of a Rapid Diagnostic Assay for Detection of SARS-CoV-2 Antigen in Nasopharyngeal Swabs. J Clin Microbiol, 2020. 58(8).

\title{
CHĂM SÓC TỔN KHUYẾT DA Ở NGƯờI BÊ̂NH SAU CHẤN THƯƠNG
}

\author{
Hoàng Văn Hồng1, Ngô Xuân Khoa ${ }^{1}$, Đinh Quang Chung ${ }^{2}$, \\ Phạm Quang Anh ${ }^{1}$, Phạm Văn Thành ${ }^{1}$, Nguyễn Thị Anh ${ }^{1}$, \\ Nguyễn Thị Hồng Nguyệt ${ }^{1}$, Phạm Thị Thanh Huyền ${ }^{1}$, Nguyễn Thị Kim Dung ${ }^{1}$,
}

\section{TÓM TẮT}

Mục tiêu:1)Mô tả quy trình chăm sóc khuyết da được ghép da dày hoặc da mỏng tại khoa Phấu thuật Tạo hình Thẩm mỹ, Bệnh viện Đại học Y Hà Nội; 2) Đánh giá mức độ hài lòng về kết quả điều trị của nhómngười bệnh nêu trên. Đối tượng và phương pháp: Nghiên cứu mô tả cắt ngang, hồi cứu hồ sớ bệnh án 33 người bệnh khuyết phần mềm do chấn thương được điêuu trị bằng phương pháp ghép da dày hoặc da mỏng tại khoa Phẩu thuật Tạo hình thẩm mỹ, Bệnh viện Đại học Y Hà Nội từ 01/8/2020 đến 11/11/2020. Kết quả: Có 33 trường hợp được đưa vào nghiên cứu, trong đó có 19 nam $(57,6 \%)$ và 14 nữ $(42,4 \%)$,tuối trung bình $31,6 \pm 17,6$ năm, cơ chế chấn thương chủ yếu do tai nạn giao thông (28trường

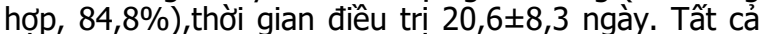
những người bệnh có tổ chức hoại tử đều được cắt lọc (12 trường hợp). Toàn bộ đối tượng nghiên cứu được băng tổn thương bằng Urgotul trước và sau ghép da.Nơi lấy da được băng bằng Betaplast 7 trường hợp (21,2\%), gạc mỡ tetracyclin 26 trường hợp (78,8\%).

${ }^{1}$ Bênh viện Đại học Y Hà Nội

${ }^{2}$ Bênh viên Hữu Nghi Viêt Đức

Chịu trách nhiệm chính: Ngô Xuân Khoa

Email: ngoxuankhoavn@gmail.com

Ngày nhận bài: 25/4/2021

Ngày phản biên khoa hoc: 22/5/2021

Ngày duyệt bài: 16/6/2021
Toàn bộ người bệnh hài lòng với kết quả điều trị. Kết Iuận: Điều trị ghép da thành công ở người bệnh khuyết phần mềm do chấn thương không chỉ phu thuộc vào kỹ thuật ghép da củaphẩu thuật viên, mà còn kỹ thuật chăm sóc của điều dưỡng. Việc áp dung kỹ thuật loại bỏ tổ chức hoại tử,sử dụng băng gạc tiên tiến trong quá trình chăm sóc giúp đạt kết quả ghép da tốt hơn.

Tư khóa: Khuyết phần mềm, chấn thương,ghép da, điều dưỡng

\section{SUMMARY} WOUND CARE IN TRAUMATIC SOFT TISSUE
DEFECT PATIENTS TREATED WITH SKIN GRAFT

Objectives: 1) Description of wound care protocol of skin defect treated by full orsplit thickness skin graft at Aesthetic Plastic Surgery Department, Hanoi Medical University Hospital; 2) Evaluate the patient's satisfaction on the outcome. Subject and methods: A retrospectivecross-sectional study. Data collection in medical records of 33 traumatic soft tissue defect participants treated by full or split thickness skin graft at Aesthetic Plastic Surgery Department, Hanoi Medical University Hospital from 01 August 2020 to 11 November 2020. Results: Thirty-three participants were included to the study. There were 19 males $(57.6 \%)$ và 14 females $(42.4 \%)$, the mean age was $31.6 \pm 17.6$ years. Traffic accident was the dominant trauma cause with total 28 cases $(84.8 \%)$, treatment duration was $20.6 \pm 8.3$ days. All necrotic tissuse was 
removed (12 cases). All soft tissue defect wound was covered by Urgotul dressing before and after skin graft. The donor site was dressed by Betaplast ( 7 cases, $21.2 \%$ ), tetracycline gauze (26 cases, $78.8 \%$ ). All patients satisfied with the outcome. Conclusion: The success of skin graft in traumatic soft tissuse defect patients not only depends on the operational technique, but also require the nursing care. Necrotic tissue removal and advanced dressing seem to have good effect on the outcome. nurse

Keywords: Soft tissuse defect, trauma, skin graft,

\section{I. ĐĂT VẤN ĐỀ}

Theo WHO, Việt Nam năm 2016, tỷ lệ tử vong do tai nạn giao thông là 26,4/100 000 dân, đứng hàng thứ 37 trên thế giới [1]. Ngoài những hậu quả nặng nề như tử vong, cắt cụt chi, còn có những hậu quả do tổn khuyết phần mềm sau chấn thương, bao gồm: giảm khả năng đi lại, khả năng tự thực hiện các công việc sinh hoạt hàng ngày, ảnh hưởng thẩm mỹ tâm lý mắc cảm vì khiếm khuyết trên cơ thể, mất đi khả năng lao động, trở thành gánh nặng của gia đình và xã hội. Việc điều tri cần có sư kết hợp nhiều chuyên khoa: chấn thương chỉnh hình, phẫu thuật tạo hình và phục hồi chức năng.Việc chuẩn bị tốt nền nhận là một bước quan trọng, giúp cho da ghép sống tốt hơn. Khi sử dụng loại băng gạc và thay băng phù hợp, có thể thúc đẩy nhanh quá trình liền thương, sức sống cũng như chức năng của da ghép, thẩm mỹ sẹo. Không có loại băng gạc nào là hoàn hảo với mọi loại tổn thương, vì vâyy, cần đánh giá tổn thương chi tiết và lựa chọn loại băng phù hợp nhất cho tổn thương cụ thể [2]. Một số loại băng thường dùng trong tổn khuyết da

Băng polyamid bọc silicon dạng lưới (Mepitel): không bị dính khi gõ̃, tuy nhiên cần thay băng để đảm bảo. Băng chứa chitosan (một dẫn xuất từ vỏ tôm): biểu mô hóa nhanh, cầm máu tốt, tuy nhiên hạn chế dùng vì chi phí đắt. Màng trứng gà: là một loại băng tự nhiên, chi phí rẻ, tuy nhiên chỉ mới dùng trên thí nghiệm, chưa có tính khả thi [3]. Betaplast: một loai băng thế hệ mới, được sử dụng rộng rãi với các tổn thương khuyết phần mềm với hiệu quả tốt.

Việc điêu trị bằng các tổn khuyểt phần mềm bằng các phương pháp chăm sóc kết hợp với sử dụng băng gạc tiên tiến đem lại kết quả tốt cho bểnh nhân. Vì vậy chúng tôi thực hiện nghiên cứu này với hai mục tiêu:

1) Mô tả quy trinh chăm sóc khuyết phần mềm được ghép da dày hoặc da mỏng tại khoa Phẫu thuật tạo hinh thẩm mỹ̃ Bệnh viện Đại học Y Hà Nội.
2) Đánh giá mức độ hài lòng của nhóm người bệnh nêu trên.

II. ĐỐI TƯợNG VÀ PHƯƠNG PHÁP NGHIÊN CỨU 2.1. Đối tượng nghiên cứu

Tiêu chuẩn lựa chọn

- Được chẩn đoán khuyết phần mềm do chấn thương

- Được điều trị bằng phương pháp ghép da

dày hoắc da mỏng

- Có đầy đủ thông tin bệnh án

Tiêu chuẩn loai trừ

- Người bệnh được điều trị bằng vạt tại chỗ hoặc vạt tự do kết hợp ghép da

- Người bệnh không đồng ý tham gia nghiên cứu

2.2. Phương pháp nghiên cứu

- Thiết kế nghiên cứu: Mô tả cắt ngang

- Thu thập số liệu:

+ Phương thức: hồi cứu

+ Chọn mấu: thuận tiện

- Thời gian và địa điểm nghiên cứu

+ Thời gian: từ 01/08/ 2020 đến 23/11/2020

+ Đia điểm: Khoa Phẫu thuâat tạo hình thẩm mỹ, Bệnh viện Đại học Y Hà Nội

- Nhập và xử lý số liệu

+ Số liệu được nhập bằng Excel và xử lý bằng $\mathrm{R}$ 3.6.0.

+ Trình bày số liệu: biến định tính (tần số, tỷ lê), biến định lượng (chuẩn: trung bình và độ lệcch chuẩn; không chuẩn: trung vị và khoảng tứ phân vị)

+ Biến số nghiên cứu: tuổi, giới, nguyên nhân chấn thương, vị trí tổn thương, diện tích khuyết phần mềm, hoại tử, lộ gân xương, phương pháp ghép da, cán da xẻ lưới, triệu chứng đau, thời gian từ khi nhập viện tới khi phẫu thuật, thời gian nằm viện, mức độ hài lòng của người bệnh

Mức độ hài lòng của người bệnh được đánh giá bằng bảng kiểm của Bộ y tế [4].

2.3. Quy trình chăm sóc người bênh ghép da tại khoa phẫu thuật tạo hình, Bệnh viện Đại học Y Hà Nội

- Trước ghép da

+ Mục đích: Làm sạch tổn thương, lên tổ chức hạt đỏ tốt, tạo điều kiện thuận lợi cho phẫu thuật ghép da.

+ Các bước thay băng

B1: Dùng nước muối sinh lý làm ẩm gạc tổn thương

B2: Sử dụng găng sạch, tháo bỏ băng gạc nhẹ nhàng.

B3: Đánh giá tình trạng tổn thương.

B4: Dùng panh Kocher rửa tổn thương bằng nước muối sinh lý để loại bỏ các dịch tiết, dùng kéo cắt lọc các tổ chức hoại tử (nếu có). 
B5: Dùng gạc thấm khô bề mặt tổn thương và đắp băng gạc tiên tiến (Urgotul hoặc Urgoclean Ag) phủ kín tổn thương

+ Mật độ thay băng

Hàng ngày hoăc cách ngày Phụ thuộc vào tình trạng tiết dịch của tổn thương

\section{- Sau ghép da}

+ Mảnhda ghép được băng ép và bất động để tạo điều kiện liền thương tốt.

+ Thời gian thay băng lần đầu cho vùng da ghép

Thông thường: 5-10 ngày [5]

Nếu băng thấm dịch nhiều, có thể thay trước 5 ngày

Không nên thay băng trước $24 \mathrm{~h}$ vì sẽ làm tăng nguy cơ bong da ghép

+ Các bước thay băng: tương tự trước ghép da

2.4. Đạo đức nghiên cứu

- Thông tin hồ sơ bệnh án được sử dụng với sự đồng ý của người bệnh

- Số liệu chỉ dùng cho mục đích khoa học

\section{KẾT QUẢ NGHIÊN CỨU}

Bảng 3.1. Đặc điểm chung

\begin{tabular}{|c|c|}
\hline \multirow{2}{*}{$\begin{array}{c}\text { Đặc điểm } \\
\text { Số người bệnh }\end{array}$} & Giá trị \\
\hline & 33 \\
\hline Giới : $\quad$ Nam & $19(57,6 \%)$ \\
\hline Nữ & $14(42,4 \%)$ \\
\hline Tuối (năm) & $31,6 \pm 17,6$ \\
\hline Nguyên nhân chấn thương & \\
\hline Tai nạn giao thông & $28(84,8 \%)$ \\
\hline Tai nan lao đông & 0 \\
\hline Tai nạn sinh hoạt & $5(15,2 \%)$ \\
\hline $\begin{array}{l}\text { Thời gian từ khi vào việnđến } \\
\text { khiphâ̂u thuật (ngày) }\end{array}$ & $7 \pm 4,4$ \\
\hline $\begin{array}{l}\text { Tổng thời gian điều trị tại viện } \\
\text { (ngày) }\end{array}$ & $20,6 \pm 8,3$ \\
\hline $\begin{array}{l}\text { hời gian từ khi phấu thuật đến kk } \\
\text { thay băng lần đâuu (ngày) }\end{array}$ & $5,5 \pm 1$ \\
\hline
\end{tabular}

Nhận xét: Đối tượng nghiên cứu chủ yếu là nam, trong độ tuổi lao động, có nguyên nhân chấn thương là tai nạn giao thông.

Bảng 3.2. Đặc điểm tổn thương khuyêt phần mềm và phương pháp phẫu thuật

\begin{tabular}{|c|c|}
\hline Đặc điểm & Giá trị \\
\hline Vị trí & \\
\hline Chi trên & $6(18,2 \%)$ \\
\hline Chi dưới & $27(81,8 \%)$ \\
\hline Kích thước $(\mathrm{cm})$ & \\
\hline Chiều dài & $28,8 \pm 16,1$ \\
\hline Chiều rộng & $16,2 \pm 8,9$ \\
\hline Hoại tữ & $12(36,4 \%)$ \\
\hline Lộ gân xương & $6(18,2 \%)$ \\
\hline Phương pháp phẩu thuật & \\
\hline
\end{tabular}

\begin{tabular}{|c|c|}
\hline Ghép da dày & $11(33,3 \%)$ \\
\hline Ghép da mỏng & $22(66,7 \%)$ \\
\hline Xẻ lưới mảnh da mỏng & $9(27,3 \%)$ \\
\hline
\end{tabular}

Nhận xét: Khuyết phần mềm ở chi dưới chiếm đa số, phương pháp ghép da mỏng được sử dụng chủ yếu.

Bảng 3.3. Chăm sóc trước và sau ghép da

\begin{tabular}{|c|c|}
\hline Can thiệp & $\mathbf{N}(\%)$ \\
\hline \multicolumn{2}{|c|}{ Trước ghép da: Tại vị trí tổn thương } \\
\hline Loại bỏ tố chức hoại tử & $12(100)$ \\
\hline Băng gạc Urgotul & $33(100)$ \\
\hline \multicolumn{2}{|c|}{ Sau ghép da Tại vị trí lấy da } \\
\hline Betaplast & $7(21,2 \%)$ \\
\hline Gạc mõ tetracyclin & $26(78,8 \%)$ \\
\hline
\end{tabular}

Nhận xét: Tốn thương được loại bỏ tố chức hoại tử (12/33 trường hợp). Tất cả các tổn thương được băng bằng gạc Urgotul trước ghép da (33/33 trường hợp). Phần lớn các trường hợp vùng lấy da ghép được băng bằng gạc mõ tetracyclin.

Bảng 3.4. Phản hồi từ người bệnh về chất lượng điều trị tại khoa

\begin{tabular}{|c|c|}
\hline Chí số đánh giá & N (\%) \\
\hline $\begin{array}{c}\text { Thái độ ứng xứ \& } \mathbf{~ n a ̆ n g ~ l u ̛ ̣ c ~ c h u y e ̂ n ~ m o ̂ n ~} \\
\text { cưa NVYT }\end{array}$ \\
\hline Hài lòng & $1(3)$ \\
\hline Rất hài lòng & $32(97)$ \\
\hline \multicolumn{2}{|c|}{ Kết quả điêu trị } \\
\hline Hài lòng & $10(30,3)$ \\
\hline Rất hài lòng & $23(69,7)$ \\
\hline
\end{tabular}

Nhận xét: Toàn bộ người bệnh có phản hồ hài lòng với chất lượng điêu trị tại khoa về thái độ ứng xử, năng lực chuyên môn và kết quả điều trị.

\section{BÀN LUÂ̂N}

4.1. Đặc điểm chung. Tất cả 33 người bệnh đủ tiêu chuẩn được đưa vào nghiên cứu. Tuổi trung bình $31,6 \pm 17,6$ năm, thấp hơn so với

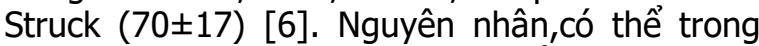
nghiên cứu của chúng tôi, các tốn khuyết của người bệnh là do tai nạn giao thông $(84,8 \%)$, còn trong nghiên cứu của Struck về bệnh nhân khuyết phần mềm sau phấu thuật ung thư $\mathrm{da}$, với tỷ lệ mắc bệnh tăng theo tuổi, phần lớn $\geq 65$ tuổi [7]. Về giới, có 19 người bệnh nam $(57,6 \%)$. Thời gian trung bình từ khi vào viện đến khi phẫu thuật là $7 \pm 4,4$ ngày. Thời gian nằm viện trung bình là $20,6 \pm 8,3$ ngày. Người bệnh trong nghiên cứu của chúng tôi thường bị chấn thương nặng, nên ngoài việc chăm sóc da ghép, sẽ cầnxử lý các tổn thương kháckèm theo, dẫn tới thời gian nằm viện dài.

4.2. Đặc điểm tổn thương và phương pháp phẫu thuật. Đa phần người bệnh bị tổn 
thương chi dưới, với kích thước trung bình là $(28,8 \pm 16,1) \times(16,2 \pm 8,9) \mathrm{cm} .12$ người bệnh tổn thương có tổ chức hoại tử và 6 người bệnh có lộ gân xương.

Có 22 người bệnh được ghép da mỏng, trong đó, có 9 trường hợp được dùng da xẻ lưới. Ớ những người bệnh được sử dụng da xẻ lưới, do diện tích tiếp xúc với nền nhận nhỏ hơn so với việc không xẻ lưới, cũng như mắt lưới dễ dính vào băng gạc, nên khi thay băng cần rất lưu ý để không bị bong da ghép khỏi nền nhận.

\subsection{Chăm sóc trước và sau ghép da}

Trước ghép da. Tổn thương được loại bỏ tổ chức hoại tử (12/33 trường hợp). Tất cả các tổn thương được băng bằng gạc Ürgotul trước ghép da (33/33 trường hợp). Phẩn lớn các trường hợp vùng lấy da ghép được băng bằng gạc mõ tetracyclin. Các phương pháp chăm sóc trên có mục đích chuẩn bị nền nhận tốt nhất. Loại bỏ các tổ chức hoại tử là một lựa chọn tối ưu, đặc biệt khi tổn thương có tổ chức hoại tử rộng hay khi có bằng chứng của nhiễm trùng. Việc loại bỏ các tổ chức hoại tử có liên quan tới thúc đẩy nhanh quá trình liền thương [3].

Sau ghép da (nơi lấy da ghép). Tất cả người bệnh ghép da dày được đắp gạc mõ tetracyclin ở nơi lấy da.

Trong số những người bệnh ghép da mỏng, số được sử dụng Betaplast và gạc mõ tetracyclin lần lượt 7 và 15 trường hợp. Nguyên nhân vì nhóm người bệnh của chúng tôi có diện tích lấy da ghép rộng, nếu sử dụng Betaplast thì sẽ tăng gánh nặng chi phí. Ngoài ra, việc sử dụng gạc mõ tetracyclin, theo kinh nghiệm tại khoa chúng tôi, mang lại hiệu quả điều trị tốt. Tuy vậy, những bệnh nhân có điều kiện tài chính, chúng tôi vẫn ưu tiên dùng Betaplast do ưu thế về độ thấm hút, dễ thay băng.

Chúng tôi đưa ra hai trường hợp điển hình cho hai phương pháp ghép da.

\section{Ca lâm sàng 1: ghép da mỏng}

Người bệnh nam, 23 tuổi, vào viện ngày 12/10/2020, khuyết phần mềm đùi gối cẳng chân trái sau tai nạn giao thông.
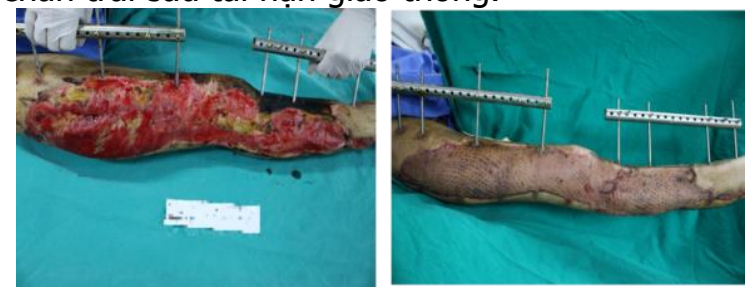

Kích thước khuyết phần mềm: mặt trước đùi: $50 \times 20 \mathrm{~cm}$, mặt trước ngoài và mặt trong cắng chân lần lượt là: $50 \times 15 \mathrm{~cm}$ và $40 \times 10 \mathrm{~cm}$, có mảng hoại tử da khô. Người bệnh được ghép da mỏng xẻ lướingày 19/10/2020, đắp gạc mõ tetracyclin ở vùng lấy da. Khi ra viện (sau mổ 35 ngày), da ghép sống tốt, khô sạch; nơi lấy da liền tốt.

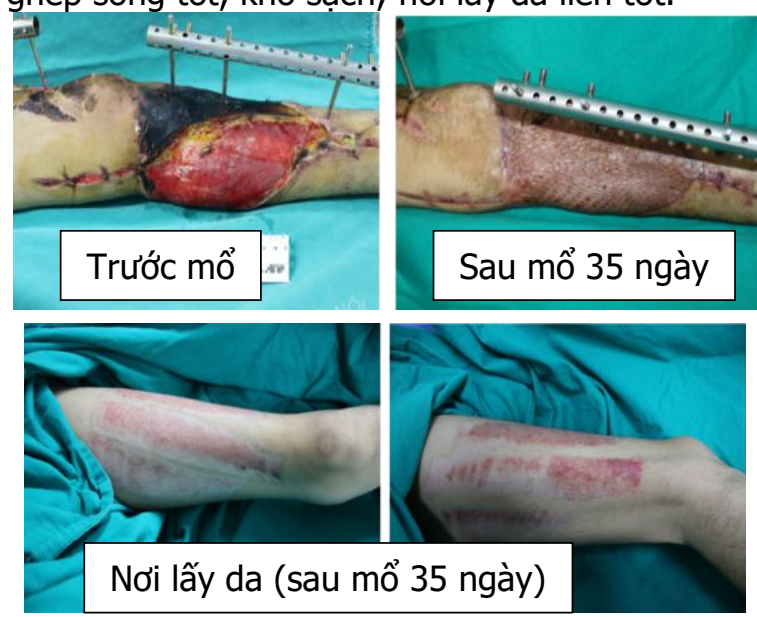

Ca lâm sàng 2: ghép da dày

Người bệnh nữ, 46 tuổi, bị tai nạn lao động máy cuốn vào tay phải ngày $29 / 10 / 2020$,cắt cụt tới $1 / 3$ trên cẳng tay phải. Người bệnh được chuyển khoa phẫu thuật tạo hình thẩm mỹ ngày 02/11/2020, khuyết phần mềm mặt trước khuỷu tay phải, kích thước $5 \times 7 \mathrm{~cm}$. Phẫu thuật ghép da

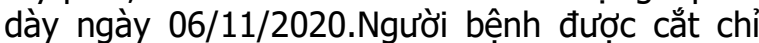
sau 14 ngày, và da ghép sống tốt trên nền nhận.

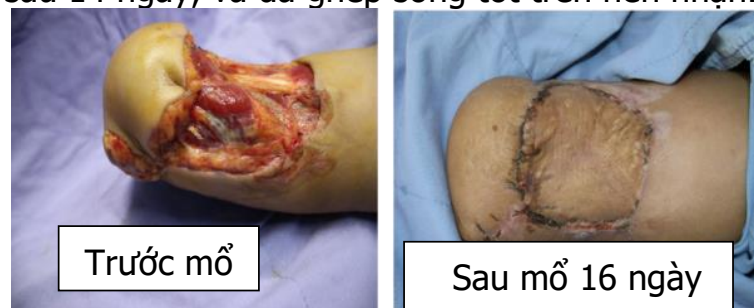

4.4. Mức độ hài lòng của người bệnh với kết quả điều trị. Tất cả người bệnh hài lòng với thái độ ứng xử, năng lực chuyên môn của nhân viên y tế cũng như kết quả điều trị (dựa vào bảng kiểm đánh giá mức độ hài lòng của người bệnh nội trú của Bộ Y tế) [4].

\section{KẾT LUÂN}

Điều trị ghép da thành công ở người bệnh khuyết phần mềm do chấn thương không chỉ phụ thuộc vào kỹ thuật của bác sĩ, mà còn cần sự chăm sóc của điều dưỡng. Việc áp dụng các kỹ thuật loại bỏ tổ chức hoại tử, sử dụng băng gạc tiên tiển trong quá trình chăm sóc có thể giúp đạt kết quả ghép da tốt hơn.

\section{TÀI LIÊU THAM KHẢO}

1. WHO Death on the roads, Data visualization.

2. Amstrong D. (2021). Basic principles of wound 
management. <https://www.uptodate.com/content s/basic-principles-of-wound-management>.

3. Spear M. and Bailey A. (2009). Treatment of Skin Graft Donor Sites With a Unique Transparent Absorbent Acrylic Dressing. Plastic Surgical Nursing, 29(4).

4. Bộ $Y$ tế Phiếu khảo sát người bệnh nội trú. $<$ http://kcb.vn/wpcontent/uploads/2016/11/Phieu-1_H\%C3\%A0i1\%C3\%B2ng-ng\%C6\%B0\%E1\%BB\%9Di-
b\%E1\%BB\%87nh-n\%E1\%BB\%99i-tr\%C3\%BA2016-pdf.pdf>

5. Gurtner G.C. Skin graft. Plastic Surgery: Principles. 4th, Elsevier.

6. Struk S., Correia N., Guenane Y., et al. (2018). Full-thickness skin grafts for lower leg defects coverage: Interest of postoperative immobilization. Ann Chir Plast Esthet, 63(3), 229-233.

7. Cancer research UK Melanoma skin cancer incidence statistics, .

\title{
NGHIÊN CỨU ĐĂC ĐIỂM LÂM SÀNG VÀ KẾT QUẢ PHỐI HỢP ĐIỀU TRI TẠI CHỖ BÊ̂NH ZONA BẰNG MEDLO TẠI PHÒNG KHÁM CHUYÊN KHOA DA LIỄU FOB CẦN THO' NĂM 2020 - 2021
}

\author{
Trần Ngọc Sĩ ***, Huỳnh Như Huỳnh*, Nguyễn Văn Nguyên**, \\ Huỳnh Hùng Anh*, Huỳnh Bạch Cúc*, Huỳnh Văn Bá*
}

\section{TÓM TẮT}

Mục tiêu: Nghiên cứu đă̆c điểm lâm sàng và kết quả phối hợp điều trị tại chỗ bệnh zona bằng Medlo tại Phòng khám chuyên khoa Da liễu FOB Cần Thơ năm 2020 - 2021. Đối tượng và phương pháp: Nghiên cứu hàng loạt ca trên 50 bệnh nhân mắc bệnh zona điều trị ngoại trú tại Phòng khám Da liễu FOB Cần Thơ năm 2020 - 2021. Kết quả: Bệnh gặp ở mọi lứa tuổi, nhóm tuổi trên 60 tuổi thường gặp nhất (chiếm 48,98\%), thấp nhất là nhóm <15 tuổi (chiếm $6,12 \%)$. Tiền triệu: Nhóm đau nhức chiếm tỷ lệ cao nhất $(77,55 \%)$, kế đến là nhóm nóng rát $(53,06)$, thấp nhất là nhóm các triệu chứng khác $(2,04 \%)$. Điều trị trước khi khám: Nhóm chưa điều trị chiếm tỷ lệ cao nhất $(51,02 \%)$, kế đến là nhóm điêu trị không chuyên khoa da liễu $(24,49)$, thấp nhất là nhóm điều tri khoán $(10,2 \%)$. Thương tôn hồng ban chiếm tỷ lệ cao nhất $(93,88 \%)$, kế đển là mụn nước, bóng nước $(79,59 \%)$, seo gặp rất ít $(6,12 \%)$. Vị trí sang thương gặp ở các vùng đâu mặt cổ và liên sườn ngực tay chiếm tỷ lệ cao nhất $(32,65 \%)$. Mức độ nhẹ chiếm tỷ lệ cao nhất $(48,98 \%)$, kế đến là nhóm mức độ nhẹ $(26,53 \%)$, thấp nhất là nhóm nặng (24,49\%). Sau 3 tuấn đâu tiên, có $100 \%$ bệnh nhân hài lòng với kết quả điều trị. Sau 7 ngày, có $60,47 \%$ bệnh đáp ứng tốt, $25,58 \%$ bênh đáp ứng khá, 13,95\% trung bình; sau 14 ngày, có $86,49 \%$ bệnh đáp ứng tốt, $10,81 \%$ bệnh đáp ứng khá, $10,81 \%$ trung bình; sau 21 ngày, có $89,19 \%$ bênh đáp ứng tốt, $8,11 \%$ bệnh đáp ứng khá, 10,81\% bểnh trung bình. Qua các tuần điều trị không ghi nhận bất kì tác dụng không mong muốn nào. Kểt luận: Thương tổn mụn nước, bóng nước gặp ở hầu hết các

*Trường Đại học Y Dược Cần Thơ

**TT GD Nghề nghiệp Thẩm mỹ FOB

***Viên Thẩm mỹ Quốc Tế $A$ \&A

Chịu trách nhiệm chính: Huỳnh Văn Bá

Email: bs.ba_fob@yahoo.com.vn

Ngày nhận bài: 29/4/2021

Ngày phản biên khoa hoc: 23/5/2021

Ngày duyệt bài: $21 / 6 / 2021$ bệnh nhân. Mụn nước, bóng nước võ có nguy cơ bội nhiễm cao, cân lưu ý vấn đề đề phòng bội nhiễm trên các bệnh nhân nổi mụn nước, bóng nước. Sau quá trình điều trị bằng thuốc uống kết hợp thuốc bôi tại chỗ bằng Medlo cho kết quả điêuu trị tốt, thuốc bôi tại chỗ không ghi nhận tác dụng phụ.

Tư khóa: Bệnh zona, đặc điểm lâm sàng, kết quả điều trị, Medlo.

\section{SUMMARY}

\section{RESEARCH ON CLINICAL}

CHARACTERISTICS AND OUTCOMES OF HERPES ZOSTER BY COMBINATION WITH MEDLO AS A TOPICAL THERAPY AT FOB DERMATOLOGY CLINIC IN 2020 - 2021

Objectives: Studying clinical characteristics and outcome of shingles by combination with medlo as a topical therapy at FOB Dermatology Clinic in 2020 2021. Methods: Series cases study on 50 patients with shingles treated as outpatients at FOB Dermatology Clinic in 2020-2021. Results: The disease was found in all ages, $\geq 60$ year-old group was the most common (accounting for $48.98 \%$ ), The lowest percentage is the $<15$ year-old group (accounting for $6.12 \%$ ). The group of pain accounted for the highest rate $(77.55 \%)$, followed by the burning group (53.06), the lowest was the group of other symptoms $(2.04 \%)$. Treatment before examination: the group of untreated patients accounted for the highest rate $(51.02 \%)$, followed by the nondermatological treatment group (24.49\%), the lowest was folk methods (non-scientific treament) (10.2\%). Erythema lesions accounted for the highest percentage $(93.88 \%)$, followed by vesicles, bullae $(79.59 \%)$, and very few scars $(6.12 \%)$. The location of the lesion was found in the head, face, neck and intercostal areas, accounting for the highest percentage $(32.65 \%)$. The mild level accounted for the highest rate $(48.98 \%)$, followed by the mild group $(26.53 \%)$, the lowest was the severe group (24.49\%). After the first 3 weeks, $100 \%$ of patients are satisfied with the treatment results. After 7 days, $60.47 \%$ of 